\title{
Değerler Eğitiminde Edebi Eserlerden Yararlanma: Fatma Aliye'nin Muhadarat Romanı Örneği ${ }^{*}$
}

\section{Utilization of Literary Texts in Values Education: The Sample of Muhadarat by Fatma Aliye}

\section{Mehmet ÖZDEMiR ${ }^{* *}$}

Öz. Değerlerin öğretiminde ve aktarılmasında edebi metinler ve edebiyat ürünleri önemli bir vasıtadır. Edebî eserler iyiyi, güzeli, doğruyu ve toplumu ayakta tutan değerleri "doğrudan" değil de sezdirerek ve estetik bir kaygı ile okuyucuya sunduğundan daha etkili ve önemli bir vasıta olarak karşımıza çıkmaktadır. Tanzimat dönemi ile birlikte şiir ve sözlü geleneğe dayanan edebiyatımıza roman ve hikâye gibi yeni türler de girmiştir. Fatma Aliye Hanım ile deilk kadın romancı olarak bu dönemde karşılaşırız. Farklı konularda roman ve makaleleri bulunan Fatma Aliye Hanım, yazmış olduğu ilk romanı Muhadarat'ta ahlaki değerleri ve öğreticiliği ön planda tutmuştur. Bu çalışmanın amacı da Türk edebiyatı tarihinde önemli bir yeri olan Fatma Aliye Hanım'ın ilk eseri olan ve farklı araştırmacılar tarafından ahlaki yönü öne çıkarılan Muhadarat isimli romanında yer alan değerleri tespit etmek ve edebi metinlerin değer öğretimindeki rolünü vurgulamak olmuştur. Araştırmada nitel araştırma yöntemlerinden biri olan doküman inceleme yöntemi kullanılmıştır. Araştırmanın verileri içerik analizi ile çözümlenmiştir. Araştırmanın sonucunda Muhadarat romanında, başta güzel ahlak, sadakat, vefa ve iyilik olmak üzere birçok değerin yer aldığı tespit edilmiştir.

Anahtar Kelimeler: Değerler eğitimi, karakter gelişimi, Fatma Aliye Hanım, Muhadarat.

Abstract. Literary texts and literary products are an important mediator in the teaching and transmission of values. Literary works emerge as a more effective and important means than offering direct to readers with aesthetic concern, not by "direct" but by "good", "sincere" and socially sustainable values. Along with the Tanzimat period, novels based on poetry and oral tradition have also been introduced, such as novels and stories. Fatma Aliye Hanım is the first female novelist and she is confronted during this period. Fatma Aliye Hanım, who has novels and articles on different topics, has written the moral values and teachings in the first novel Muhadarat, which she wrote. The aim of this study was to determine the values in the novel named Muhadarat, which was the first work of Fatma Aliye Hanım and which was pointed out by different researchers and which emphasized the role of literary texts in value teaching. In the research, document analysis method which is one of the qualitative research methods was used. The content of the research was analyzed by content analysis. As a result of the research, it has been found that in the novel of Muhadrat, many values, especially good morals, loyalty, loyalty and goodness, are involved.

Keywords: Values education, character development, Fatma Aliye Hanım, Muhadarat.
Toplumsal Mesaj. Bu çalışmanın amacı Türk edebiyatı tarihinde önemli bir yeri olan Fatma Aliye Hanım'ın ilk eseri olan ve farklı araştırmacılar tarafından ahlaki yönü öne çıkarılan Muhadarat isimli romanında yer alan değerleri tespit etmek ve edebi metinlerin değer öğretimindeki rolünü vurgulamaktır.

Public Interest Statement. The aim of this study was to determine the values in the novel named Muhadarat, which was the first work of Fatma Aliye Hanım and which was pointed out by different researchers and which emphasized the role of literary texts in value teaching.

\footnotetext{
* Bu çalışma VIII. Uluslararası Lisansüstü Eğitim Sempozyumunda bildiri olarak sunulmuştur.

** Yrd. Doç. Dr., Sakarya Üniversitesi, Eğitim Fakültesi, Türkçe Sosyal Bilimler Eğitimi Bölümü, mehmetoz@sakarya.edu.tr

${ }^{* * *}$ Arş. Gör., Sakarya Üniversitesi, Eğitim Fakültesi, Türkçe Sosyal Bilimler Eğitimi Bölümü, ferideidi@sakarya.edu.tr 


\section{GíRiş}

Toplumdaki ahlaki yapının bozulması, eğitim sisteminde değerler eğitimini ve karakter gelişimini gündeme getirmiştir. Son on yıl içerisinde gerek öğretim programlarında gerekse eğitimin farklı alanlarında değerler eğitimi kendine yer bulmakta ve bununla beraber çocukta ve bireyde karakter gelişimi önemsenmektedir. Özellikle Türkçe ve Edebiyat dersleri değerlerin öğretimi ve aktarımında önemli bir vasıtadır. Cemiloğlu (2009:20) edebiyatın üç yönüyle eğitimde etkili olduğundan bahseder: dil eğitimi, estetik eğitimi ve ahlak eğitimi. Dolayısıyla Türkçe eğitiminde en temel materyal olarak karşımıza çıkan edebi ürünlerden seçilen metinlerin sadece estetik ve dil açısında mükemmel olması yeterli değildirMetinler, Türkçe eğitiminde öğrencilere sadece dil bilgisi kurallarını öğretmek ya da okuma alışkanlığı kazandırmak için değil, aynı zamanda değerleri öğretmek için de kullanılmaktadır (Şen, 2007: 53). Edebî metinlerin dünyasına girme alışkanlığı edinmiş birey, insanların çok çeşitli duyma, düşünme ve hareket etme örnekleriyle tanışır, kendini başkalarının yerine koyabilir, özdeşim kurma yeteneği oluşturur, insan kişiliğine saygı duyar, hoşgörülülük kazanır, insanların değişik özelliklerde olabileceği gerçeğini anlar. Bu süreç, insanın yeni yaşantılar edinme, kişiliğini değiştirme ve geliştirme sürecidir (Sever, 1998: 4-5).

Karakter eğitiminin amacı öğrencileri iyiyi bilen, iyiyi arzulayan ve iyiyi yapan bir birey yapmaksa, biz bu sonuca ulaşmak için öğrenciler için otantik, anlamlı ve ilgili yollar bulmalıyız. Karakter eğitimini geliştirmekte bir yol edebiyatı kullanmaktır (Edgington, 2002: 116). Edebiyat eserleri hem bireysel hem de toplumsal hayatla ilgili olarak iyiye, güzele, doğruya yönelme ve yeni değerler kazandırma yolunda telkinlerde bulunur, insanları bunlar doğrultusunda eğitir (Kavcar, 1999: 6). Dolayısıyla öğrencilere küçük yaştan itibaren okuma alışkanlığı kazandırmak ve onları edebi metinlerle tanıştırmak zihinsel gelişimleri açısından birçok yararı barındırdığı gibi karakter gelişimlerine de katkıda bulunmakta ve öğretmeyi amaçladığımız değerleri kendiliğinden kazanmalarını sağlamaktadır. Okuma kitapları, ilköğretim çağı çocuğunun hayal dünyasını geliştirmek, üslûp sahibi olmasını sağlamak, dil becerilerini geliştirmek, kişilik gelişimine katkıda bulunmak, milî̂, manevi, ahlaki, evrensel, kültürel, insani değerleri edindirmek açısından son derece etkili bir materyaldir (Şen, 2007: 54). Karakter geliştirme temalarına sahip iyi bir edebiyat eseri, öğrencilere önemli temel etik değerleri yerleştirmeye yönelik gerekli önermeleri geliştirip şekillendirir ve güçlendirir (Almerico, 2014: 3). Bunun en iyi örüntüsüne içerisinde karakter yoğunluğuna ve dinamik insan ilişkilerine sıklıkla başvurulan edebi türlerde karşılaşılmaktadır. Bu türler arasında olaya dayalı türlerden olan öykü, değerleri çocuk ile buluşturan en önemli edebi ürünlerden biridir. Çocukların hayatlarında, kültürel değerlerin çoğunlukla biçimi verildiğini ve anlamlı olduğunu vurgulayan öyküler önemli bir rol oynar (Leming, 2000: 413). Öykü ile birlikte farklı edebi türler de bu amaca hizmet etmektedir. Karakter eğitimi kavramları, edebiyat bağlamında öğretildiğinde, öğrenciler saygı, dürüstlük, cesaret ve şefkat gibi özelliklerin çevrelerindeki dünyanın gerçek ve ilginç yönleri olduğunu fark eder (Almerico, 2014: 3). Bireyin alt yapısına, algılarına ve duygularına göre yeniden üretilen eserler, bireyin estetik değerlerinin gelişimine, kullanılan dilin öneminin kavranmasına, bireysel ve toplumsal değerlerin farkına varılmasına imkân sağlamaktadır (Aras, 2014). Edebi eserler bireyin hayatında küçüklükten itibaren önemli bir yer tutmakta ve karakter gelişimlerinde oldukça etkili olmaktadır. Aynı zamanda etkili bir değerler eğitiminin verilmesinde de edebi eserlerin vazgeçilmez bir materyal olduğu yadsınamaz bir gerçektir.

Son otuz yıldır okullarda değerlerin öğretiminde dört yaklaşım kullanılmaktadır. Bunlar; değerlerin telkini (değer öğretimi), değerlerin açıklanması, değer analizi ve ahlaki akıl yürütmedir (Edgington, 2002: 113). Değerlerin telkin edilmesinde anlatarak ve açıklayarak öğretme söz konusudur. Bu yaklaşımın temel çıkış noktası, devamlı ve kalıcı değerlerin öğrencilere telkin edilmesi bir başka ifade ile aşılanmasıdır (Yazııı, 2006: 510). Değer açıklama yaklaşımında öğretmenin telkin ve yönlendirmesi olmaksızın öğrencinin kendi değerlerini bulması sağlanır. Öğrencinin mevcut değer seçeneklerinden her birisini sonuçları ile değerlendirmesi ve bağımsız bir şekilde kendi savunduğu değeri belirlemesi gerekir (Meydan, 2014: 102). Değer analizi; empoze edilen değerlere karşı olarak 
ya da sadece onları açıklayarak, değerler konularını analiz etmeyi ve değerler kriterleri ile uygun biçimde hüküm vermeyi sağlar (Naylor ve Diem, 1987: 352). Ahlaki muhakeme yaklaşımı; Kohlberg tarafından geliştirilen bu yaklaşımda amaç öğrencilere verilen ahlaki ikilem içeren hikâyelerle onların ahlaki yargılarını ortaya çıkarmaktır (Akbaş, 2004: 100). Değerlerin öğretiminde ve aktarılmasında kullanılan bu yaklaşımlar değerlendirildiğinde edebi metinlerle değer öğretiminin bu yaklaşımlardan birçoğu ile uygunluk gösterdiği anlaşılmaktadır. Edebiyatın, olay ve kişilere dayalı metinlerinde anlatma; duygu ve hayale dayalı metinlerinde sezdirme, birtakım fenomenlerini canlandırmada ise gösterme veya görsel anlatı tekniği kullanıır. Örneğin, masal, hikâye ve roman gibi edebî metinlerin oluşturulmasında anlatma sanatı kullanılırken; şiir gibi duygu ve hayale dayalı metinlerde sezdirme; tiyatro, resim ve heykel gibi ürünlerin oluşturulmasında ise görsel anlatı kullanılır (Karatay, 2007: 465). Edebi metinlerle değer öğretiminde; değer açıklama, değer analizi ve ahlaki muhakeme yaklaşımlarından faydalanmak mümkündür ve bu yaklaşımların uygulamaya geçmesinde edebi metinler iyi bir vasıtadır. Edebi eserlerin büyük bir bölümü, insanları çeşitli bakımlardan eğitmek amacıyla yazılmıştır. Türk Edebiyatı'nda Yunus Emre, birçok şiirini ve Risaletü'n-Nushiyye (Öğüt Kitabı) adlı eserini, Mevlana Mesnevi'sini, Nabi Hayriyye'sini, Namık Kemal tiyatro eserlerinin çoğunu, Ahmet Mithat romanlarını, Tevfik Fikret Haluk'un Defteri ve Şermin adlı eserlerini, Mehmet Akif Safahatını, Hüseyin Rahmi romanlarını ve daha pek çok şair ve yazar, eserlerini hep insanlara nasıl yaşanılması, nelere değer verilmesi gerektiğini öğretmek amacıyla yazmışlardır. (Kavcar,1994: 3). Görüldügü üzere edebiyat eserlerinde, geçmişten günümüze kadar gelinensüreçte edebi metinler aracıllğıyla her zaman iyiyi ve güzeli anlatmak önemli bir amaç olmuştur.

Yazılı ve sözlü geleneğe dayanan edebiyat tarihimizde Tanzimat dönemi itibariyle, makale deneme, röportaj, fıkra türlerinin yanında, roman ve hikâye gibi yeni türler edebiyatımıza girmeye başlamıştır. Bu ilk eserler incelendiğinde de edebiyat eserlerinin birçoğunda gözlemlediğimiz değer ve ahlak öğretiminin yoğun bir şekilde yer aldığı görülmektedir. Özellikle Tanzimat sanatçıları, edebiyatı toplumu eğitmek için bir vasıta olarak görmüşler ve edebîliği ikinci plânda tutmuşlardır. Yapılan bu araştırmaya konu olan Fatma Aliye Hanım da edebiyat tarihimizin ilk kadın roman yazarı olması ve döneminde birçok esere imza atmasıyla büyük bir önem taşımaktadır. Tanzimat döneminin önemli bir yazar ve aydını olan Fatma Aliye Hanım (1862-1936), konusunu kadınların oluşturduğu beş roman, ayrıca dönemin gazete ve dergilerinde kadın sorununu ele alan çok sayıda makale yazmıştır (Gençtürk Demircioğlu, 2010: 105). Kadın erkek eşitliği, kadının eğitimi ve çalışması, evlenme şekilleri, çok eşlilik, boşanma, İslam'da kadının yeri, sosyal hayatta görünür olma gibi kadınlığı doğrudan ilgilendiren konular onun eserlerinin başlıca konusu olmuştur (Karaca, 2011: 95). Modern Türk edebiyatının ilk kadın yazarlarından birisi olan Fatma Aliye Hanım'ın okuyucuya, kendi evlilik yaşamından da kesitler sunduğu intibaını veren ve kendi adıyla yayımladığı ilk romanı "Muhadarât" (1892) tır (Er, 2011: 386). Tanzimat romanlarındaki sosyal işlev ve Servet-i Fünun romanlarındaki yüksek zümreye hitap etme amaçlarından farklı olarak Muhadarat'ta bir inanç ve ahlak amacı vardır. Bu anlamıyla bir ahlak romanıdır (Kırtıl, 2003: 124). Fatma Aliye Hanım'ın millî ve mukaddes değerlere bağlılı̆ı -neredeyse- her eserinde kendini göstermektedir. Özellikle, kendisine büyük şöhret kazandırmış olan Muhadarat romanında, Fazıla'nın hayat seyrinde dini duygular birçok kötülüğe engel olmuştur (Aşa, 1996: 7).

\subsection{Araştırmanın Amacı}

Bu araştırmanın amacı Türk edebiyat tarihinde önemli bir yeri olan Fatma Aliye Hanım'ın ilk eseri olan ve farkı ıraştırmacılar tarafından ahlaki yönü ön plana çıkarılan Muhadarat isimli romanın yer verdiği değerleri tespit etmek ve edebi metinlerin değer öğretimindeki rolünü vurgulamak olmuştur. 


\section{YÖNTEM}

Bu araştırmada nitel araştırma yöntemlerinden olan doküman inceleme yöntemi kullanılmıştır. Doküman inceleme, belgesel tarama olarak belirtilen, geçmişteki olguların izlerini taşıyan resim, film vb. yapıtları, olgularla ilgili olarak yayınlanmış kitap, dergi vb. birtakım yazıı materyalleri analiz etmek için kullanılan nitel araştırma yöntemidir (Karasar, 2008: 183). Çalışmanın verileri ise içerik analizi ile değerlendirilmiştir. İçerik analizinde temelde yapılan işlem birbirine benzeyen verileri belirli kavramlar ve temalar çerçevesinde bir araya getirmek ve okuyucunun anlayabileceği bir biçimde düzenleyerek yorumlamaktır (Yıldırım ve Şimşek, 2013: 259). iç̧erik analizi yapılırken kod ve kategoriler kullanıımıştır. Araştırmada elde edilen kategorilere her biri için onu en iyi temsil ettiği varsayılanaçıklamalardan örnekler seçilerek bulgular bölümünde yer verilmiştir (Yıldırım ve Şimşek, 2013). Araştırmanın güvenirliğini sağlanması için iki farklı alan uzmanı tarafından kodlamalar ayrı ayrı yapılmış ve tutarlıı̆ı teyit edilmiştir. Çelişkiye düşülen durumlarda üçüncü bir alan uzmanına başvurularak ortak bir görüş birliğine varılmıştır.

\section{BULGULAR}

Bu bölümde Muhadarat romanında tespit edilen güzel ahlak, sadakat, iyilik, vefa, kadirşinaslık, dürütlük, namus, dedikodu, Allah inancı ve iffet değerleri, romandan örnekler verilerek yorumlanmıştır. Romanda karşılaşılan değer ifadelerinin sıklığı ve çeşitliliği ölçüsünde örnekler verilmiştir.

\subsection{Güzel Ahlâk}

Arapça "hulk" kelimesinin çoğulu olan ve "huylar" anlamına gelen ahlâk, toplumiçinde huzurlu yaşamayı sağlamak için toplum tarafından konulmuş, kişilerin uymak zorunda oldukları davranış biçimleri ve kurallardır (Özdemir ve Kaplan, 2015: 118). Muhadarat romanında ahlakive güzel ahlâklı olmaya yönelik değerlere özellikle yer verildiğigörülmektedir. Güzel ahlaka yönelik değerler romanda en sık rastlanan değerler arasındadır.

Yazar, romanın başkahramanı Fazıla ve ailesinin gittikleri dügün evini tasvir ederken güzellik kavramına değinir, güzel ve çirkinden bahseder. Sonrasında ise güzel ahlâkın kalpleri "lezzetyab" eden önemine şu cümlelerle değinir:

"Her azası güzeller gibi olup da yine çirkin olanlardaki o çirkinlik de kemal-i hayretle temaşa edilecek (büyük bir hayranlıkla seyredilecek) hikmetlerden değil midir? Ol çirkinler içinde dahi o kadar hüsn-i ahlak (güzel ahlak) sahipleri, vefadar ve sadık ahbap bulunur ki güzellerin gözlerimizi mütelezziz eyledikleri (gözlerimize hoş görünmesi) kadar onlar da kalplerimizi lezzetyab eylerler (kalplerimize hoş gelirler) (Fatma Aliye, 2012: 17-18).

Romanın başkahramanı Fazıla, arkadaşı Fevkiye'ye düğün evindeki muhabbetleri esnasında güzel ahlakın, insan eğitimindeki önemineşu cümlelerle vurgu yapar:" -Zaten hüsn-ü ahlak ashabını (sahiplerini) tatlıık muti (itaatkar) ve bet muamele asi eder. Tehdit ile terbiye ahlakı bozuk olanlara göredir (Fatma Aliye, 2012:22).

Fazıla ve arkadaşı Fevkiye arasında geçen konuşmada, Fazıla'nın üvey annesiCalibe Hanım'ın ona ve kardeşine yaptığı kötülükler mevzu bahis olunca Fevkiye, Fazıla'ya bunlardan babasına bahsetmesini önerir. Bunun üzerine Fazıla, kendileri zor durumda kalmalarına rağmen:" -Bir zevceyi zevcine zemmetmek (karıyı kocasına yermek) kadar şenaat ve denaet (kötülük ve alçaklık) olamaz (Fatma Aliye, 2012:24) diyerek, "ahlaklı olma"nın güzel bir örneğini sergiler.

Aslında Calibe, eski aşkı ve amcasının oğlu olan Süha'ya karşı, parayı tercih edip Sai Efendi ile evlenecek kadar ahlâk yoksunu bir insandır. Romanda karşılaşılan ve eleştirilen bir başka ahlaksızlık, Fazıla'nın evlenmek zorunda kaldığı fakat zamanla bağlandığı kocası Remzi'nin onu başka kadınlarla aldatmasıdır. Bu tavır Fazıla'yı intihar etme düşüncesine kadar sürükler. Romanda yazarın kurguladığı bu hadiseler sonuçta "güzel ahlak"ın önemine vurgu yapan gelişmelerdir. 


\subsection{Sadakat}

Sadakat; içten bağ|lık, sağlam, güçlü dostluk (TDK, 2009: 1675) anlamlarına gelmektedir. Romanda sadakatle ilgili değerler büyük ölçüdeMünevver Hanım'ın komşuluğunda ve arkadaşının öksüz kalan çocuklarına olan ilgisinde kendini göstermektedir.

Romanda annelerinin ölümü ile yetim kalan Fazıla ve Şefik karakterlerine, komşuları olan Münevver Hanım'ın sahip çıkması ve onları koruyup gözetmesi anlatıııken vefayla birlikte sadakate de vurgu yapılmaktadır. Münevver Hanım, eve çok sık geldiğinden Calibe'nin çocuklara kötü davrandığını, tam bir üvey annelik yaptığını gördüğünden kendisine birçok nasihatlerde bulunur. Calibe, Münevver Hanım'a bundan dolayı çok soğuk davranmasına rağmen Münevver Hanımın, Mukaddem Bey'in annesine göstermiş olduğu sadâkat ve vefaya dayalı dostluğu romanda şöyle yer alır:" -Ben buraya ancak şu çocukların hatırı için geliyorum, diye Calibe Hanım'ı tanımadığını suret-i nazikhanedeifham eylemiş olduğundan Calibe bütün bütün komşu hanımefendiye hiddet eylemişti. Fakat Münevver Hanım'ın vefat eden zevci, Sai Efendi'nin sevgili komşusu ve sadık dostu olduğu gibi Fazıla ile Şefik'in validelerinin vefatından sonra Münevver Hanım'ın Sai Efendi'nin gerek hanesi, gerek çocukları için pek çok hizmetleri sebkat eylemişti (Fatma Aliye, 2012:45).

Fazıla'nın annesinin vefatından sonra onu ve kardeşini yalnız bırakmayıp destek olan Münvevver Hanım ve oğlu Mukaddem'e borcunu ödemek isteyişinden bahsedilirken de onun sadakatine şu cümlelerle vurgu yapılır:

"Validesi ve oğlu şimdiye kadar benim ve kardeşim için müş̧ik ve medetkârdılar (yardımcıydılar). Ben onlara olan borcumuzu hanelerine gittiğim vakit itaat ve sadakatle ödeyeceğim diye müteselli oluyordum. Şimdi ise onların bunca iyiliklerinin mukabilini ne ile ödeyeceğim bilir misin matmazel?" (Fatma Aliye, 2012: 161).

Münevver Hanım ve Fazıla'nın ağzından aktarılan bu ve buna benzer ifadeler romanda sadakat değerini sadece nasihat edilerek kazandırılmaya çalışılan bir kavram olarak değil hayatın içinde var olan bir davranış olarak öne çıkarmaktadır.

\section{3 İyilik}

İyilik, karşıık beklenilmeden yapılan yardım, kayra, lütuf, kerem, ihsan, inayet (TDK, 2009: 1007)) anlamlarındadır. Romanda da iyilik değerine sıkça yer verilmektedir veMünevver Hanım'ın, özellikle oğlunu terbiye edişi anlatılırken iyiliğe özendirmesi: "Oğluylamusahabeti esnasında hep birçok iyi insanların medh ü senasını ederek iyilik ve insaniyeti pek güzel zihnine yerleştirdiği gibi yine birçok insanı zemmederek fenalıktan nefret ettirirdi (s.54) cümleleri ile vurgulanmaktadır. Ve bu cümleler aynı zamanda kötülüklerden nefret ettirmekle de insanlara iyilik değerinin kazandırılabileceği ifade edilmektedir.

\subsection{Vefa}

Vefa, sevgiyi sürdürme, sevgi bağlılı̆ı (TDK, 2009: 2084) anlamındadır. Romanda ise vefa değerine gerek yapılan vefasızlığın vicdan azabını göstererek gerekse de vefalı davranışlara yer verilerek değinilmiştir.

Sai Efendinin kızı Fazıla'ya gezmek için gittiği yeri sormasının ardından, Fazıla'nın annesinin mezarına gitmek istediğini söylemesiSai Beyi düşüncelere gark eder ve vefat eden eşine olan vefasızlığı aklına gelir. Aslında Sai Bey'in vefasızlığının ifade edildiği cümlelerle iç içe Fazıla'nın annesine olan bağlıı̆ından da bahsedilmiş olması, yazarın başarısını gözler önüne sermektedir. Bu durum romanda şu cümlelerle yer alır:

"Fazıla mezardan bahsediyor, mezardan! Sai Efendi zevcesiz bulunduğu bir sene müddette ekseri gidip de hasbihal eylediği ve yerine zevce getirdikten sonra bir daha gitmek aklına gelmediği mezardan. Fakat bu on dört yaşındaki bir çocuğun aklına gelmiş ve kendisine ilk defa nereye gitmek istediği sorulduğu zaman orasını söylüyor. Sai Efendi bir gaflet uykusundan uyanır gibi bir hal ile o zamana kadar olan vefasızlığına ve bunu bir çocuğun kendisinin hatırına getirdiğine mahcup oluyordu." (Fatma Aliye, 2012:56) 
Mukaddem ve Fazıla arasında geçen konuşmada, Mukaddem'in annesi Münevver Hanım'ın, Fazıla'nın annesine hastalığı süresince gösterdiği vefalı davranış söz konusu olur. Komşular arasında bugüne de örnek olabilecek bu davranış romanda:

"Baksana Mukaddem! Eğer aramızdaki münasebet ve hukuk yalnız bir zaman ben senin nişanlın bulunmaklığım olsaydı, bizim bir daha birbirlerimizi düşünmek ve yekdiğerimizi arayıp sormaklığımız hiç münasebet almazdı. Fakat kendimi tanıdığım ve hala hatırlayabildiğim zamanlarda ben validemin yanında senin valideni gördüm. Ona "hemşirem ve yegâne muhibbe-i vefa şiarım" dediğini işittim. Validem genç yaşında hastalanıp da bir daha kalkmak nasip olmayan yatağa düştüğü zaman ben valideni onun başı ucunda buldum. Mualecede kusur edilmesin diyerek vakit ve saatinde eliyle ilacını veren o mürüvvetkar kadındı. Pederim de onun bu derece insaniyet ve vefakârlığına minnettar olarak ona dua eyliyordu. Biçare valideciğim, ecelden kendini kurtaramayacağını anladığı zaman evlatlarını ona tavsiye eylemişti." (Fatma Aliye, 2012:293) şeklinde yer alır. Bugün bireyselliğin özgürlük olarak anlaşıldığı ve insanların yalnızlaştığı dünyada, komşuluğun ve komşular arası bağıı̆ı̆ın bu derece öne çıkarılması gerçekten yaşatılması gereken bir değer olarak önem kazanmaktadır.

Yukarıda yer alan hadiseden sonra, Fazıla'nın Mukaddem'in rahatsızlı̆ı ile bizzat ilgilenip, ona ve annesi Münevver Hanım'a olan vefa borcunu ödemek için bütün gücüyle çabalamasını anlatan:

"Fazıla, Mukaddem'e uykusunu ve rahatını terk ederek bakıyordu. Sa'yinin boşa gitmediğini, Mukaddem'in günden güne kesb-i afiyet eylemekte olduğunu görmekle memnun oluyordu. Münevver Hanım da Mukaddem'in yanında bulunsa ancak bu kadar bakabilirdi. Fazıla Mukaddem'e eylediği hizmetle gerek Münevver Hanım'ın gerek Mukaddem Bey'in kendisine olan haklarını ödemekte olduğundan dolayı memnun oluyordu. Fazıla, her şeye nezaret eylediği cihetle, konak içinde çamaşır yıkamaktan muaf bulunduğu ve onun işi yıkanıp ütülenen çamaşırları yerleştirmek olduğu halde, Mukaddem'in çamaşırlarını kimseye bırakmayıp kendisi yıkıyordu. Mukaddem, kendisi için onun bu kadar çalışmasını istemiyor ve o kadar kendini yormaması için ona rica eyliyorsa da Fazıla, eğer onun işi kendisine ağır gelmiş olsa çırakları olan cariyelere gördürebileceğini, kendisine tevdi olunan vazife yalnız yukarı hizmetleri ile aşağıda görülen hizmetlere nezaret olduğunu, yaptığı işi kendi gönlünün rızasıyla yapmakta bulunduğunu ve kendilerine olan minnettarlı̆̆ı icabınca ona hizmet etmek, kendisinebüyük bir lezzet geldiğini Mukaddem'e bildirdi." (Fatma Aliye, 2012:321) cümleleri, önce karşılıklı bir vefa duygusunun ve değerinin öne çıkarıldığını, ancak bununla da yetinilmeyip karşılıklı güven duygusunun da ancak böyle "vefalı" bir davranış ile sağlanabileceğini ortaya koyması açısından dikkat çekmektedir.

\subsection{Kadirşinaslık}

Kadirşinaslık, değerbilirlik, iyilikbilirlik (TDK, 2009: 1029) anlamlarına gelmektedir. Romanda üvey anne Calibe ile amcasının oğlu Süha Bey arasında eskiye dayanan bir ilişki vardır. Ancak Calibe, para için Sai Efendi'yi tercih etmesine rağmen Süha Bey ile olan ilişkisini de devam ettirmektedir. Bu durumdan rahatsız olan Süha Bey'in Calibe Hanım'a hitaben söylediği ve pişmanlık ifade eden:

"Beni asıl sen nankör ettin. Hanesine sığındığım, ekmeğini yediğim bir zat-ı ali karda karşı küfran-ı nimet ve hıyanet ettirdin. Şimdiye kadar rahat yediğim ekmek o adamın sofrasında ve karşısında bulunduğum halde artık boğazımdan güçlükle geçiyor. Yüzüne bakmaya utanıyorum. Bütün gün kendi alçaklı̆ımı düşünerek mustarip oluyorum." (Fatma Aliye, 2012:75)cümleleri, aslında Sai Efendi'ye hak ettiği değeri vermemekten ve ona ihanet etmekten kaynaklanan bir vicdan azabını ifade etmenin yanında, kadirşinas davranılması gereken bir kişiye tam tersi yapılan davranıştan duyulan pişmanlığın da dile getirilmesi açısından önem taşımaktadır.

\subsection{Dürüstlük}

Romanda Fazıla'nın, üvey annesi Calibe Hanım ve onun aşığı Süha Bey'in kendisine karşı düzenledikleri hilelerden haberi yoktur. Anlatıı yazar, Fazıla'nın içinde bulunduğu güç durumu şu cümlelerle ortaya koyar:

"Lakin kendini nasıl müdafaa eyleyecek? Bunun için aleyhinde tertip olunan desayise kesb-i vukuf eylemesi lazım değil mi? Buna nasıl muvaffak olabilecek? Fazıla'nın da onlara karşı hile ve hud'a tertip 
edemeyecek kadar istikameti (dürüstlüğü) ve ahvale kesb-i vukuf ile (olan biteni öğrenmekle) ona göre davranmak için kapılardan dinlemeye tenezzül edememek için de uluvv-i cenabı (iyiliği) var." (Fatma Aliye, 2012:145).

Bu ifadeler ile Fazıla'nın karakterindeki dürüstlük ve iyilik özelliklerinden dolayı kendisine komplo düzenleyen üvey annesi ve üvey annesinin amcazadesi Süha Bey'e onlarınki gibi bir karşılık vermeyeceği ortaya koyulurken, Fazıla'nın taşıdığı "dürüstlük" ve "iyilik" değerleri ön plana çıkarılmışır.

\subsection{Namus}

Romanda üzerinde durulan ve öne çıkarılan önemli değerlerden bir diğeri de "namus" değeridir. "Bir toplum içinde ahlak kurallarına karşı beslenen bağlıık" (TDK, 2009: 1455) olarak tanımlanan namus kavramı Sai Efendi'nin kızı Fazıla'ya hitaben söylediği şu cümlelerde ele alınmıştır: "Ben senin bunu ne için yaptığını bilirim ama sen ondan ümidi kes! Mademki lakırdı bu kadar açıldı. Ben de sana şunu söyleyeyim ki senin bundan sonra Mukaddem'e varmak ihtimalin yok. Bunu hatırından sil de benim vakar ve haysiyetime dokunacak muamelatta bulunayım deme. Ben namus uğrunda değil evlat, canımı feda ederim" (Fatma Aliye, 2012: 155).

Çünkü Sai Bey, üvey anne Calibe Hanım ve onun amcazadesi Süha Bey tarafından ortaya atılan, Mukaddem'in, sarhoş bir anında evin hizmetçisi Reftar ile gizli bir ilişki yaşadığı ve böylece nişanlısı Fazıla'yı aldattığı yönündeki iftira ile kandırılmıştır. Bunun üzerine namus konusunda çok hassas olan Sai Efendi yukarıdaki konuşma ile namus uğruna değil evlâdını, canını bile "feda" edeceğini Israrla vurgular.

\subsection{Dedikodu}

İnsanların yüzlerine karşı söylenemeyecek sözlerin, onların olamadığı bir yerde ve arkalarından söylenerek yapılan olumsuz bir davranış olan dedikodu, gıybet olarak da isimlendirilir ve toplum tarafından yadırganan bir durumdur. Romanda ele alınan ve eleştirilen dedikodu olumsuz bir tavır olarak şu cümlelerle ele alınır: "Her insan için bir şeyle iştigal eylemek bir emr-i fıtri (yaratıış gereği) olup, insanların kimi çifţ̧ilik, kimi sanatkârlık, kimi gemicilik ve kimi ulûm ve fünun, velhasıl her biri bir şeyle iştigal eyledikleri halde, işsiz bulunanların ümmî olanları meşguliyetine doyulmayan okumak yazmaktan mahrum olduklarından dedikodu ve fitnelikle iştigal ede geldikleri aşikâr olarak görülen ahvaldendir. Iş̧te bu "dedikodu" tabir olunan çirkin şeyin de kadınlar nezdinde mebzuliyeti işsizlikle cehlin onlarda ekseriyetle mevcudiyetinden ileri gelmiyor mu?" (Fatma Aliye, 2012:196).

Dedikodu yapmanın, insanların arkasından konuşmanın, "işsizlerin" ve "okuması yazması olmayanların" başvurdukları "çirkin" bir davranış olduğu vurgulandıktan sonra, bu durumun kadınlarda görülmesi ise özellikle kadınların "ekseriyetle" işsiz ve cahil bırakılmaları ile izah edilmeye çalışılmıştır.

\subsection{Allah İnancı}

"Allah inancı" da toplumun önemli değerlerindendir. Romanda, Fazıla'nın yaşadığı sıkıntılar sonrasında intiharın eşiğine gelmesi ve tam intihar edecekken bunun Allah'a isyan etmek olduğunun farkına vararak bu teşebbüsünden vazgeçmesi anlatılırken "Allah inancı"na yapılan vurgu şöyle ifade edilmektedir: "Ben seni akıllı, müdebbir ve muti bir kı diye severdim! Sonra da o yolda devam eylediğin için benim ruhum mütelezziz oluyordu. Sen pederine ve validene itaatsizlik etmediğin halde halikine karşı isyan mı ediyorsun? Onun nehyeylediği bir şeyle amel etmeye mi cesaret eyliyorsun? Geri!...Geri!...Ben bu yolda gelen evladı yanıma kabul etmem!" (Fatma Aliye, 2012:280).

Fazıla'nın, annesinin hayali ile konuşması şeklinde kurgulanan bu sözler ile Allah'ın yasakladığı bir davranış olan "intiharın", ancak "Allah inancı" ile engellenebileceğine dikkat çekilmiştir.

\subsection{0 iffet}

Fazıla, intihar etmekten vazgeçer ancak, intihar ettiği zannedilsin diye mendilini ve bileziğini uçurumun kenarında bırakarak oradan uzaklaşır. Bir esir pazarında Beyrutlu zengin bir aileye "cariye" olarak satılıp İstanbul'dan ayrılır. Bu süre zarfında kocası hayatta olduğu ve nikâhları 
devam ettiği için hiçbir erkekle görüşmez ve gelen evlenme tekliflerini reddeder. Bir günŞebib'in okuduğu gazeteden kocası Remzi'nin ölüm haberini öğrenir ve bunun üzerine çalıştığı konakta yaşayan Şebip Beyin evlenme teklifine olumlu bakmaya başlar. Ondaki bu değişim romanda şu cümlelerle anlatılır: "Fazıla, tamamıyla kendini topladığı vakit Şebip'e eylediği teşekkürü, o zamana kadar ona bakmadığı bir nazarla bakarak ifa eyliyordu. Fazıla artık hür ve serbestti. Gayrı üzerinde bir zevç hakkı bulunmadığından, Şebip'e istediği gibi bakabilmekte kendisini muhtar buluyordu. Fazıla, bir diğerinin nikahlısı olduğu halde dikkatle erkeklere bakabilmek salahiyetini kendinde görememiş olduğundan, o zamana kadar Şebip'e dikkatle bakmamıştı." (Fatma Aliye, 2012:356).

Görüldüğü gibi Fazıla, ondan ayrı olmasına rağmen kocası Remzi ilehâlâ nikâhlı olduğundanbu süre zarfında erkeklere yan gözle bile bakmayarak iffetine ve namusuna söz getirmemiştir. Ne zaman ki kocası ölür ondan sonra üzerinde bir nikâh hakkı kalmamıştır. Dolayısıyla bir başka evliliği düşünmesinde, inancı açısından, engel kalmamıştır.

\section{SONUÇ}

Tanzimat döneminin önemli romanlarından olan, çeşitli özellikleri ile dikkat çekip ön plana çıkmasına ve farklı araştırmacılar tarafından ahlaki yönüne vurgu yapılmasına rağmen bugüne kadar aktardığı değerler açısından incelenmemiş olan Muhadarat romanının birçok değeri aktardığı yapılan bu çalışma ile ortaya koyulmaya çalışıımıştır. Romanda yer alan değerler arasında öne çıkanlar; güzel ahlak, sadakat, iyilik, vefa, kadirşinaslık, dürüstlük, namus, Allah inancı ve iffet'tir. Güzel ahlak, sadakat ve vefa değerlerine roman genelinde en çok üzerinde durulan değerler olarak rastlanırken bu değerleri iyilik, dürüstlük ve Allah inancı değerleri sıklıkla karşılaşılan değerler olarak takip eder. Kadirşinaslık, namus, dedikodudan kaçınma ve iffet değerleri de romanda yer alan değerler arasındadır. Tanzimat döneminde kaleme alınan ve yazıldığı dönemin sosyokültürel özelliklerini yansıtan Muhadarat romanının odak noktasını oluşturan "aile hayatı" ve "kadın-erkek ilişkileri" gibi umum konular, romanda tespit edilen değerlerin doğası ile örtüşen bir yapıda karşımıza çıkmaktadır.

Edebi eserlerin bireyin karakter gelişiminde ve bireylere değer aktarımında önemli rol oynadığı yadsınamaz bir gerçek olduğundan bu değerlerin ele alınış şekilleri ve bunlara karşı yöneltilen dikkat sayesinde okuyucunun hassasiyetleri harekete geçirilmeye çalışılımıştır. Ayrıca, bütün bu değerlerin, birer nasihat cümleleri ile değil de hayatın akışı içinde verilmiş olması okuyucu üzerindeki etkisini artıracak bir tercih olarak görülmektedir.

Öğrencileri nitelikli edebiyat eserleri ile buluşturmak, onların gerek zihinsel gerek duygusal gelişimlerini sağlamak ve onlara okuma alışkanlığı kazandırmak açısından büyük önem arz etmektedir. Bunu yaparken milli ve manevi değerlere öncelik vermeli ve bu bağlamda yazılmış geçmişten günümüze kadar gelen eserlerin okutulmasına özen gösterilmelidir. Fatma Aliye Hanım'ın Muhadarat romanına bu açıdan bakıldığında yukarıda ortaya koyulan amaçları gerçekleştirebilecek nitelikleri taşıdığı görülmektedir.

\section{Kaynakça}

Akbaş, O. (2004). Türk Milli Eğitim Sisteminin Duyuşsal Amaçlarının İlköğretim II. Kademedeki Gerçekleşme Derecesinin Değerlendirilmesi. Doktora Tezi. Gazi Üniversitesi Eğitim Bilimleri Enstitüsü.

Almerico, G. M. (2014). BuildingCharacter Through Literacy With Children's Literature. Research in Higher Education Journal, 26, 1-13.

Aras, G. (2014). Insan ve Toplum: Edebiyat ve Değerler Eğitimi. Akademik Bakış Dergisi, 44. http://dergipark.gov.tr/abuhsbd/issue/32936/365897 adresinden erişilmiştir.

Cemiloğlu, M. (2009). ilköğretim Okullarında Türkçe Öğretimi (5. Baskı). Bursa: Alfa Akademi. 
Edgington, W. D. (2002). To Promote Character Education, Use Literature for Children and Adolescents. The Social Studies, 93(3), 113-116. DOI:10.1080/00377990209599893.

Er, D. (2011). Fatma Aliye (Topuz) Hanım (1862-1936) ve Kadının Toplumdaki Yeri Hakkındaki Fikirleri. E-Journal Of New World Sciences Academy, 6(2), 380-395.

Fatma Aliye Hanım (1996). Muhadarat (Yayına Haz. Emel Aşa). İstanbul: Enderun Kitabevi.

Fatma Aliye Hanım (2012). Muhadarat (Yayına Haz. Fazıl Gökçek). İstanbul: Özgür Yayınları.

Karaca, Ş. (2011). Fatma Aliye Hanım'ın Türk Kadın Haklarının Düşünsel Temellerine Katkıları. Karadeniz Araştırmaları, 31, 93-110.

Karasar, N. (2008). Bilimsel Araştırma Yöntemi. Ankara: Nobel Yayınları.

Karatay, H. (2007). Dil Edinimi ve Değer Öğretimi Sürecinde Masalın Önemi ve İşlevi. Türk Eğitim Bilimleri Dergisi, 5(3), 463-475.

Kavcar, C. (1999). Edebiyat ve Eğitim. Genişletilmiş 3. Basım. Ankara: Engin Yayıncılık.

Kırtıl, O. (2003), "Fatma Âliye ve Muhâdarât'ı”. Kadın Araştırmaları Dergisi, 8, 101-26.

Leming, J. S. (2000). Tell Me A Story: An Evaluation Of A Literature-Based Character Education Programme. Journal of Moral Education, 29(4), 413-427, DOI:10.1080/713679388.

Meydan, H. (2014). Okulda Değerler Eğitiminin Yeri ve Değerler Eğitimi Yaklaşımları Üzerine Bir Değerlendirme. Bülent Ecevit Üniversitesi Ilahiyat Fakültesi Dergisi, 1(1), 93-108.

Naylor, D. T. ve Diem, R. (1987). Elementary and Middle School Social Studies. New York: Random House.

Özdemir, M. ve Kaplan, T. (2015). Ahmet Mithat Efendi'nin “Çingene" Romanında Çingene Gerçeği ile ilgili Öne Çıkan Değerler. RouteEducationalandSocialScienceJournal, 2(1), 115-129.

Sever, S. (2000). Türkçe Öğretimi ve Tam Öğrenme. Ankara: Anı Yayınları.

Şen, Ü. (2007). Milli Eğitim Bakanlığının 2005 Yılında Tavsiye Ettiği 100Temel Eser Yoluyla Türkçe Eğitiminde DeğerlerÖğretimi Üzerine Bir Araştırma. Yüksek Lisans Tezi, Gazi Üniversitesi, Eğitim Bilimleri Enstitüsü.

TDK (2009). Türkçe Sözlük. Ankara: Türk Dil Kurumu Yayınları.

Yazıcı, K. (2006). Değerler Eğitimine Genel Bir Bakış. TÜBAR, 19, 499-522. 


\section{Extended Summary}

Today, when the structure of the changing society is examined, various moral problems are encountered. The corruption of the moral structure in society has brought about the education of values and character development in the education system. Literary products and literary texts are inevitably nowadays, as children are teaching in value and in their character and moral development. If the goal of character education is to help students know the good, desire the good, and ultimately do the good, we must find ways to achieve that end that are authentic, meaningful, and relevant for our students. One way is to use literatüre to cultivate character education (Edgington, 2002: 116). Good literatüre with character development themes has the power to develop, shape, and reinforce dispositions essential for instilling in students important core ethical values (Almerico, 2014: 3). In the last thirty years, four approaches to teaching values have been used in schools: values in culcation, values clarification, values analysis, and moral reasoning. When these approaches used in teaching and transferring values are evaluated, it is understood that value teaching with literary texts is compatible with many of these approaches. In our literary history based on written and oral tradition, newgenres such as essays, interviews, articles, novels and stories began to enter our literature as of Tanzimat period. When these first works are examined, it is seen that the value and moral education which we observed in most of the literary works takesplace intensively. Fatma Aliye Hanım, who is the subject of this research, has a great importance as her literary history is the first female novel writer and she has signed many works during her period.

The purpose of this research was to determine the values of the novel named Muhadarat, which was the first work of Fatma Aliye Hanım and which was an important place in the history of Turkish literature and which was set in the foreground by the different researchers, and to emphasize the role of literary texts in value teaching.

In this research, document analysis method which is one of qualitative research methods is used. The data of the study was evaluated by content analysis.

Featured forward through the values contained in the novel; good morality, faithfulness, goodness, loyalty, gratitude, honesty, honor, God is faith and chastity. It is an undeniable fact that literary works play an important role in character development and transfer of value to individuals. Therefore, the sensitivity of readers has been tried to be actuated by the way these values are handled and the attention paid to them.

Connecting students with qualified literary works is of great importance in terms of providing them with both mental and emotional development and giving them reading habits. In doing so, we must first give priority to our own national and spiritual values and cares hould be taken to read the works from the past to the present day written in this context. When Fatma Aliye Hanim's Muhadarat novel is viewed from this point of view, It appears that she possesses the qualities that can realize the aims set out above. 